Стаття надійшла

до редакції : 10.09 .2018 p.

\section{Стаття прийнята}

до друку: 20.11.2018 p.

Бібліографічний опис для цитування :

Костирко Л. А. Пріоритети фінансового контролінгу в управлінні вартістю господарюючих суб’ єктів / Л. А. Костирко, М. В. Свтушенко // Часопис економічних реформ. - 2018. - № 4 (32). - С. 38-45.

УДК 336.228 .326

JEL Classification: E63; H20

ЛІХОНОСОВА Г. С.

\title{
ВАРІАЦІЇ ЕФЕКТИВНОСТІ ЗАПРОВАДЖЕННЯ ІНСТРУМЕНТІВ ПОДАТКОВОГО РЕГУЛЮВАННЯ
}

\author{
DOI: 10.32620/cher.2018.4.07
}

Постановка проблеми. Сьогоденні умови соціально-економічного стану України актуалізують необхідність податкового регулювання, а саме впровадження різних варіантів інструментів податкового стимулювання. Проте, варто чітко розуміти подальші наслідки відповідного реформування та тенденції ефективності впровадження відповідних інструментів. Мета статті - проаналізувати існуючі варіації ефективності впровадження інструментів податкового регулювання задля виявлення можливості оптимізації порядку податкового регулювання та стимулювання. Об'єкт дослідження процес визначення ефективності від запровадження інструментів податкового регулювання. Мето$\partial u$, використані в дослідженні: логічно-змістовний метод, системний підхід, монографічний метод, методи індукції та дідукції тощо. Гіпотеза дослідження. Наявність залежності між ефективністю податкового регулювання завдяки співставлення результатів надання податкових пільг з втратами бюджету та якісними характеристиками конкретних категорій платників. Виклад основного матеріалу. Розрахунок коефіцієнта бюджетної ефективності впровадження інструментів податкового стимулювання, можна здійснювати за через показники обсягу податкових надходжень до бюджету за оцінюваний період та за період, що передує оцінюваному, а також обсягу податкових пільг, що надаються в оцінюваному періоді. Орихінальність та практичне значення дослідження полягають в обгрунтуванні методичного інструментарію визначення ефективності запровадження різних варіантів податкового регулювання. Висновки дослідження. Наразі існує достатня кількість методик оцінювання ефективності заходів податкового стимулювання, проте вибір будь-якої з них вимагатиме доопрацювання у частині визначення інструментарію, критеріїв, а найголовніше - мети, яку передбачається досягти у результаті їі впровадження.

Ключові слова:

податкове регулювання, ефективність, стимулювання, бюджетні витрати, дохід, податкові агенти.

\section{VARIATIONS OF EFFICIENCY OF IMPLEMENTATION OF TOOLS TAX ADJUSTMENT}

Formulation of the problem. The current conditions of the socio-economic state of Ukraine make the need for tax regulation more urgent, namely the introduction of various options for tax incentives. However, there is a need to clearly understand the further consequences of the relevant reform and the effectiveness of the implementation of the relevant instruments. The aim of the research is to analyze the existing variations in the effectiveness of the introduction of tax regulation instruments in order to identify the possibility of optimizing the tax regulation and incentive arrangement. The object of research is the process of determining the effectiveness of the introduction of tax regulation tools. The methods used of the research: logicalcontent method, system approach, monographic method, methods of induction and deduction. The hypothesis of research. The existence of a relationship between the effectiveness of tax regulation by comparing the

${ }^{1}$ Ліхоносова Ганна Сергіївна, канд. екон. наук, доцент кафедри «Фінанси», Національний аерокосмічний університет ім. М. С. Жуковський «Харківський авіаційний інститут», м. Харків, Україна.

Likhonosova Ganna, Ph.D. in Economics, Assistant professor of Finance Department National Aerospace University «Kharkiv Aviation Institute», Kharkiv, Ukraine.

ORCID ID: 0000-0001-6552-8920

e-mail: a.likhonosova@gmail.com 
results of providing tax breaks with budget losses and qualitative characteristics of specific categories of payers. The statement of basic materials. The calculation of the fiscal efficiency of the introduction of tax incentives can be done through the indicators of tax revenues in the budget for the estimated period and for the period preceding the estimated one, as well as the amount of tax benefits provided in the period under assessment. Originality and practical significance of the research consist in substantiating the methodical tools for determining the effectiveness of introducing various options for tax regulation. Conclusions of research. There are currently a number of techniques for assessing the effectiveness of tax incentive measures, but the selection of any of them will require further elaboration in terms of defining the tools, criteria, and most importantly, the goal that is expected to be achieved as a result of its implementation.

Key words:

tax regulation, efficiency, incentives, budget expenditures, income, tax agents.

\section{ВАРИАЦИИ ЭФФЕКТИВНОСТИ ВНЕДРЕНИЯ ИНСТРУМЕНТОВ НАЛОГОВОГО РЕГУЛИРОВАНИЯ}

Постановка проблемы. Сегодняшние условия социально-экономического состояния Украины актуализируют необходимость налогового регулирования, а именно внедрение различных вариантов инструментов налогового стимулирования. Однако, следует четко понимать дальнейшие последствия соответствующего реформирования и тенденции эффективности внедрения соответствующих инструментов. Цель статьи - проанализировать существующие вариации эффективности внедрения инструментов налогового регулирования для выявления возможности оптимизации порядка налогового регулирования и стимулирования. Объект исследования - процесс определения эффективности от внедрения инструментов налогового регулирования. Meтоды, использованные в исследовании: логически-содержательный метод, системный подход, монографический метод, методы индукции и дидукции тому подобное. Гипотеза исследования. Наличие зависимости между эффективностью налогового регулирования благодаря сопоставление результатов предоставления налоговых льгот с потерями бюджета и качественными характеристиками конкретных категорий плательщиков. Изложение основного материала. Расчет коэффициента бюджетной эффективности внедрения инструментов налогового стимулирования, можно осуществлять с через показатели объема налоговых поступлений в бюджет за оцениваемый период и за период, предшествующий оцениваемому, а также объема налоговых льгот, предоставляемых в оцениваемом периоде. Оригинальность и практическое значение исследования заключаются в обосновании методического инструментария определения эффективности внедрения различных вариантов налогового регулирования. Bыводы исследования. Сейчас существует достаточное количество методик оценки эффективности мероприятий налогового стимулирования, однако выбор любой из них потребует доработки в части определения инструментария, критериев, а главное - цели, которую предполагается достичь в результате ее внедрения.

Ключевые слова:

налоговое регулирование, эффективность, стимулирование, бюджетные расходы, доход, налоговые агенты.

Постановка проблеми. Податкове регулювання як цілеспрямована державна функція, базується на активному використанні існуючої незалежно від прагнення суб'єктів господарювання, процесу регулювання податків заради отримання певних соціальноекономічних результатів. Тобто податкове регулювання $\epsilon$ цілеспрямованим впливом держави на поведінку економічних агентів завдяки використанню методів та інструментів податкової політики для досягнення позитивних соціально-економічних результатів для країни.

Одним із завдань процесу податкового регулювання в країні $є$ гармонійне поєднання того податкового, соціально-економічного та управлінського інструментарію, який застосовується у зв'язку з встановленням податкових обов'язків для відповідних категорій платників. Основним інструментом податкового регулювання та стимулювання, безумовно, виступають податкові пільги. Проте кількість наданих податкових преференцій, яких за аналізом фахівців [1, с. 45], наразі налічується вже більш 300, не свідчить про якість, результативність їхнього впровадження.

Наразі в Україні оцінювання втрат доходів бюджету здійснюється на підставі форм статистичної та податкової звітності суб'єктів господарювання, а також Порядку 
обліку сум податків і зборів, не сплачених суб'єктом господарювання до бюджету у зв'язку з отриманням податкових пільг, який не дозволяє зрозуміти ступень результативності та ефективності надання податкових пільг [2]. Даний порядок регламентує облік бюджетних втрат через надання пільг виключно 3 податку на додану вартість, залишаючи поза увагою інші податки. Крім того, зазначений нормативний акт дозволяє отримати інформацію лише про суми втрат бюджету, не враховуючи їхнього впливу на поведінку та реакцію суб'єктів господарювання.

Аналіз останніх досліджень та публікацій. Н. Г. Лукова підкреслює [3], що показники бюджетних втрат, розраховані згідно 3 Порядком [2], є відносними, оскільки при їхньому розрахунку не береться до уваги мультиплікаційний ефект, що об'єктивно виникає при наданні податкових пільг. Деякі дослідники відзначають, що використання різних методів кількісної оцінки податкових витрат призводить до формування різних переліків податкових витрат, оскільки метод еквівалентних витрат застосовується лише до тих статей, які можуть бути замінені на прямі витрати, що адмініструються державним агентством [4].

Фахівці науково-дослідного інституту фінансового права значну увагу приділяють методикам визначення ефективності заходів податкового стимулювання [5], акцентуючи на тому, що універсальної методики визначення ефективності впровадження податкового регулювання не існує, саме національні аспекти економічного розвитку мають ставати відправними точками визначення можливості та ефективності заходів податкового регулювання.

О. Молдован зазначає, що кожна держава сьогодні прагне не лише створити сприятливий фіскальний простір для інноваційної діяльності, а й запропонувати інвесторові більший обсяг фіскальної підтримки, ніж надають інші країни, з метою заохочення саме на iii території. Дана конкуренція змушує уряди різних країн постійно вдосконалювати фіскальні інструменти підтримки інноваційної діяльності [6, с. 20].
Мета статті - проаналізувати існуючі варіації ефективності впровадження інструментів податкового регулювання задля виявлення можливості оптимізації порядку податкового регулювання та стимулювання.

Виклад основного матеріалу дослідження. Більшість цивілізованих країн світу мають власні офіційно затверджені методики визначення ефективності заходів податкового стимулювання та запровадження податкових пільг. Узагальнення певних підходів до оцінювання ефективності податкових пільг свідчить про значну диференціацію у визначенні форм і методик розрахунку показників ефективності.

Оцінювання ефективності податкового регулювання та стимулювання передбачає зіставляння результатів надання податкових пільг з втратами бюджету на основі використання кількісних показників економічної, бюджетної та соціальної ефективності або якісних характеристик у розрізі окремих податків відповідно конкретної категорії платників.

Під бюджетною ефективністю прийнято розуміти оцінку впливу податкової пільги на формування доходів відповідного бюджету. Оцінювання бюджетної ефективності 3 практичної точки зору можливо проводити на основі розрахунку кількісних показників: 1) на основі порівняння втрат бюджету від надання пільг і приросту доходу (економії втрат) бюджету у зв'язку з наданням податкових пільг; 2) на основі порівняння витрат бюджету на здійснення підтримки у формі пільги та альтернативних варіантів організації даної підтримки; 3) на основі розрахунку суми чистих наведених надходжень до бюджету від категорії платників податків, якій надано пільгу; 4) на основі додавання приросту доходів у результаті збільшення податкової бази по кожному виду пільг і збільшення фонду оплати праці і зниження витрат бюджету; 5) на основі порівняння втрат бюджету за оцінюваний період і втрат бюджету за попередній період.

Найпростіший спосіб це - оцінювання шляхом зіставлення втрат бюджету від надання пільги і приросту податкових платежів, які виникнуть від iii застосування [7, с. 241] 
Розрахунок коефіцієнта бюджетної ефективності впровадження інструментів податкового стимулювання, можна здійснювати за формулою:

$$
\kappa_{\text {бе }}=\left(\Pi \mathrm{H}_{t}-\Pi \mathrm{H}_{t-1} / \Pi_{t}\right)+1,
$$

де $\mathrm{K}_{\text {бе }}$ - коефіцієнт бюджетної ефективності; ПН ${ }_{t}-$ обсяг податкових надходжень до бюджету за оцінюваний період; $\Pi \mathrm{H}_{t-1}$ обсяг податкових надходжень до бюджету за період, що передує оцінюваному; $\Pi_{t}-$ обсяг податкових пільг, що надаються в оцінюваному періоді. При значенні більше або дорівнює 1,00 бюджетна ефективність податкових пільг визнається прийнятною (достатньою). При значенні менше 1,00 бюджетна ефективність податкових пільг визнається недостатньою (низькою).

Соціальна ефективність являє собою соціальні наслідки податкового стимулювання, що визначаються показниками, які відображають значущість підтримуваної за допомогою податкової пільги діяльності платника податків, або показниками, що підтверджують створення сприятливих умов розвитку інфраструктури соціальної сфери та підвищення соціальної захищеності населення (створення нових робочих місць, поліпшення умов праці, збільшення доходів громадян, збереження робочих місць для малозабезпечених і соціально незахищених верств населення, а також поліпшення екологічної ситуації тощо).

Кількісні показники, що дозволяють оцінити соціальну ефективність, розраховуються, як правило, окремо при наданні пільг організаціям і фізичним особам. Щодо організацій розрахунок здійснюється на основі: 1) добутку відношення коштів організацій, яким надана податкова пільга, що витрачаються на соціально важливі цілі, до втрат бюджету і темпів зростання кількості наданих платниками податків робіт (послуг), сум виплаченої середньої заробітної плати, кількості створених робочих місць, до надання пільги (або за період, що передує звітному періоду) і після надання пільги (або у звітному періоді); 2) додавання приросту вартості наданих послуг організаціями, що надають послуги населен- ню, приросту фонду оплати праці в результаті створення нових робочих місць та наданої пільги; 3) добутку відношення приросту фонду заробітної плати до приросту прожиткового мінімуму в розрахунку на душу населення та коригуючого коефіцієнта цільової спрямованості діяльності платників [7, с. 241-242] . Щодо платників податків фізичних осіб розрахунок кількісних показників оцінки соціальної ефективності здійснюється на основі: добутку коефіцієнта потреби платників податків у соціальній підтримці та темпу зростання народжуваності, темпу зростання кількості платників податків, яким надана податкова пільга, які потребують поліпшення житлових умов, і темпу зниження заборгованості платників податків 3 оплати житловокомунальних послуг; на основі розрахунку коефіцієнта купівельної спроможності фізичних осіб.

Економічна ефективність відображає результативність витрат та економічної діяльності платників податків, яким надана пільга. Оцінка проводиться на основі розрахунку кількісних показників: 1) на основі співвідношення приросту інвестицій і суми податкових пільг; 2) на основі співвідношення приросту виручки від реалізації продукції та суми втрат бюджету.

Таким чином, і при оцінці ефективності не існує єдиного підходу. Віднесення перерахованих показників до показників ефективності є дискусійним питанням. Особливо це стосується якісних показників соціальної ефективності. Серебрянський Д. зазначає, що аналіз вітчизняних та іноземних наукових праць не дає однозначної відповіді на питання доцільності податкових пільг у національних системах оподаткування [5, с 7]. Враховуючи глибинність бюджетної проблематики, національні уряди, незважаючи на дискусійність такого визначення, мають жорстку позицію відносно податкових пільг.

В сучасних умовах потрібно обрахувати різні ефекти, які можуть виникнути через впровадження заходів податкового регулювання. Оскільки саме отримання декількох ефектів, у тому числі й бюджетного, буде закономірною після впровадження певного інструменту податкового стимулювання. 
Фіскальний ефект податкового стимулювання повинен являти собою приріст наступних податкових доходів над поточними податковими витратами. Під перевищенням податкових доходів розуміється різниця між сумою податкових надходжень 3 ряду взаємозалежних податків, обчислюється в умовах надання пільги в періоді, коли проявляється реальний ефект від дії даного податкового інструменту, та сумою податкових надходжень за відсутності дії даного інструменту в аналогічному за тривалістю періоду до іï введення.

Соціальний ефект податкового стимулювання проявляється в підвищенні рівня життя населення, збереженні та розвитку соціально значущих сфер діяльності, формуванні сприятливих умов життедіяльності для соціально незахищених верств населення, збереженні та створенні нових робочих місць Прояви цього ефекту для території зрозумілі, проте точна кількісна оцінка не може бути визначена. Через необхідність очищення отриманого ефекту від загального фону підвищення рівня життя і поліпшення соціального добробуту населення території, що зробити досить складно, оскільки на даній території може бути кілька підприємств, що формують даний ефект.

Економічний ефект податкової пільги, проявляється у збільшенні фінансових ресурсів платника податків, які перебувають у його розпорядженні у зв'язку з відсутністю необхідності перераховувати ці кошти в бюджет держави у вигляді податків. Це може значно поліпшити фінансовий стан підприємства, забезпечивши більш високу платоспроможність і ліквідність, вирішити завдання прискореної модернізації основних фондів, збільшити прибуток. Даний ефект проявляється у випереджаючій динаміці інвестицій в основний капітал, у розширенні та оновленні виробництва і технологій з метою збільшення обсягів виробництва, випуску конкурентоспроможної продукції та створенні нових робочих місць (у тому числі модернізованих), збільшенні прибутку.

Бюджетний ефект податкового стимулювання проявляється не тільки в подальшому збільшенні доходів бюджету, отриманих за рахунок розширення податкової бази в результаті дії інструменту стимулювання та в економії бюджетних коштів, які раніше витрачалися на вирішення соціальноекономічних завдань. Таким чином, мова йде про появу в результаті дії інструментів податкового стимулювання додаткових бюджетних коштів, які можуть бути витрачені на вирішення пріоритетних завдань відповідного регіону. Ці додаткові бюджетні кошти виникають внаслідок збільшення податкових надходжень, тобто доходів бюджету, та економії бюджетних коштів при реалізації соціальноекономічних завдань.

Висновки та перспективи подальших досліджень. Таким чином, на сьогодні існує достатня кількість методик оцінювання ефективності заходів податкового стимулювання, проте вибір будь-якої з них вимагатиме доопрацювання у частині визначення інструментарію, критеріїв, а найголовніше - мети, яку передбачається досягти у результаті іiі впровадження. Дана проблема повинна знайти своє вирішення на державному рівні шляхом прийняття офіційного нормативно-правового акта. Залежно від того, хто стане видавником такого документа, буде задекларовано мету даної методики, адже різні органи виконавчої влади зацікавлені і несуть відповідальність лише за окрему сегмент роботи у системі державного управління, яка законодавчо встановлена у їх функціях. Так, якщо методика оцінки податкових пільг буде розроблена для потреб Державної податкової адміністрації України, то вона, ймовірно, буде містити лише бюджетну ефективність (у вузькому значенні), Міністерства фінансів України - фіскальну ефективність, Міністерства економічного розвитку і торгівлі України - економічну ефективність, Міністерства соціальної політики України - соціальну ефективність. Виходячи 3 цього, видавником нормативно-правового акта, який затвердить методику оцінки ефективності податкових пільг, має стати Кабінет Міністрів України - виконавчий орган, який, за Конституцією України, забезпечує проведення податкової політики.

Подальші дослідження будуть спрямовані на моніторинг результативності реалізації інструментів податкового регулювання, 
виходячи 3 того, що здатності вибудувати ефективний механізм реалізації податкових інструментів, який дозволяв би компенсувати значну частину витрат від запровадження податкових пільг, зокрема, та чітко обмежував би спроби використати пільги для мінімізації оподаткування.

\section{Література}

1. Теоретико-прикладні аспекти інвентаризації податкових пільг, передбачених українським законодавством. - Ірпінь : НДІ фінансового права, 2013. - 60 с.

2. Лукова Н. Г. Ефективність податкових пільг, які надаються суб'єктам господарювання / Н. Г. Лукова // Вісник Інституту економіко-правових досліджень НАН України. -2001 . - № 2. - С. 68.

3. Порядок обліку сум податків та зборів, не сплачених суб'єктом господарювання до бюджету у зв'язку 3 отриманням податкових пільг : Постанова Кабінету Міністрів України. № 1233 від 27.12.2010 р. // Офіційний вісник України. - 2011. - № 1. Ст. 18.

4. Оцінка ефективності заходів податкового стимулювання: основні теоретичні підходи та їх реалізація щодо національної економіки. - Ірпінь : НДІ фінансового права, 2013. -48 c.

5. Carasso A., Steuerle E. Tax Expenditures: Revenue Loss Versus Outlay Equivalents // Tax Notes. October 13, 2003. Vol. 7. P. 287.

6. Молдован О. Податкові інструменти стимулювання науково-дослідних і дослідно-конструкторських робіт у світовій практиці / О. Молдован // Світ фінансів. - 2014. № 2. - C. 20-27.

\section{Стаття надійшла}

до редакції : 10.10.2018 p.
7. Экономика налоговых реформ : монография / [под ред. И. А. Майбурова, Ю. Б. Иванова, Л. Л. Тарангул]. - К. : Алерта, 2013. $-280 \mathrm{c}$.

8. Орлова Е. Н. Роль налоговых расходов местных бюджетов в формировании налогового потенциала / Е. Н. Орлова, С. С. Быков // Проблеми економіки. - 2012. - № 3. - C. 37-40.

\section{References}

1. Theoretical and applied aspects of the inventory of tax benefits provided for by Ukrainian legislation (2013). Irpen: SRI of financial law, 60.

2. Lukova, N. G. (2001). Efficiency of tax privileges granted to economic entities. Bulletin of the Institute of Economic and Legal Studies of the National Academy of Sciences of Ukraine, 2, 68.

3. Procedure for accounting for amounts of taxes and fees not paid by the entity to the budget in connection with obtaining tax privileges: Resolution of the Cabinet of Ministers of Ukraine. № 1233 dated 27.12.2010. (2011). Official bulletin of Ukraine, 1, 18.

4. Evaluating the effectiveness of tax incentives: the main theoretical approaches and their implementation in relation to the national economy. (2013). Irpen: SRI of financial law, 48

5. Carasso, A. \& Steuerle, E. ( 2003). Tax Expenditures: Revenue Loss Versus Outlay Equivalents. Tax Notes. October 13, 7, 287.

6. Moldovan, $O$. (2014). Tax instruments for stimulation of research and development works in world practice. World Finance, 2, 2027.

7. Mayburova, A. \& Ivanova, Yu. \& Tarangul, $L$. (2013). The economy of tax reforms: a monograph. Kyev: Alerta, 280.

8. Orlova, E. N. \& Bykov, S. S. (2012). The role of tax expenditures of local budgets in the formation of the tax potential. Problems of the economy, 3, 37-40.

до друку: 20.11.2018 p.

Бібліографічний опис для цитування :

Ліхоносова Г. С. Варіації ефективності запровадження інструментів податкового регулювання / Г. С. Ліхоносова // Часопис економічних реформ. - 2018. - № 4 (32). - С. 46-51. 